\title{
INTRODUCTION November 2018
}

\section{Introduction}

$1 \quad$ Priti Parikh CEng, MICE, FRSA

Senior Lecturer, University College London, UK
2 Philippe Bouillard CEng, FICE, SFHEA

Professor, Université Libre de Bruxelles, Belgium

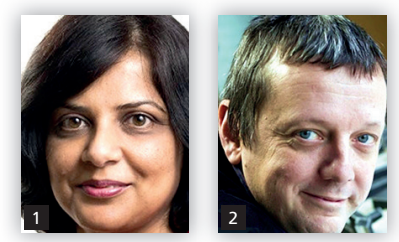

Welcome to the November 2018 special issue of Civil Engineering on cities of the future, which looks at a critical challenge facing humanity.

Currently, more than $50 \%$ of world's population lives in urban areas, placing huge demands on infrastructure, services, climate and environment (World Bank, 2009). Projections show that another 2.5 billion people will live in urban areas by 2050 (UN, 2014). Our cities therefore need substantial investment in infrastructure services to sustain human and economic activity to be fit for the future.

Civil engineers are well placed to make cities better places to live, both improving access to infrastructure and leading on innovation to ensure that scarce environmental resources are used judiciously. As we celebrate 200 years of the Institution of Civil Engineers (ICE), the members of which have contributed so much to creating our built environment (ICE, 2018), now is a perfect time to reflect on the role of civil engineers in shaping our future and making our cities liveable as they continue to grow.

Rogers (2018) starts by showing how civil engineers can build better cities through a deeper understanding of future benefits, resilience and value creation with infrastructure. He presents three methods that enable civil engineers to design resilient cities through exploring extreme scenarios, assessing whether cities are liveable through establishing whether an intervention meets the aspirations of citizens, and assessing value created for various beneficiaries of infrastructure investment.

Hoornweg et al. (2018) next present an approach to measure and prioritise urban infrastructure for planners and policy makers. By way of example, the method is applied to nine transportation projects in Canada and compared with projects in Brazil, China, India and Senegal.

Dolman and Ogunyoye (2018) look specifically at fresh water scarcity in cities and how different water challenges such as flood risk can shape future cities. They illustrated this with case studies that focus on water-resilient design, water-sensitive design and regeneration of existing water services.

von der Tann et al. (2018) explore the potential of use of underground spaces in cities for placing infrastructure services. The subsurface provides stability for buildings, water and materials and can accommodate significant infrastructure. The authors review current initiatives in industry, policy and research, and propose that more needs to be done to capture value from the subsurface for sustainable and resilient cities.

Jackson (2018) discusses the role of offshore engineering in meeting future energy and space needs of cities. He says floating offshore structures can increase usable space in cities by developing over water and delivering energy and transport infrastructure.

Clancy et al. (2018) describe how a government-funded scheme is helping London's borough to develop electric charging infrastructure to reduce vehicular emissions and improve air quality by 2050 . The authors discuss site challenges, innovative solutions developed by individual boroughs and programme-level challenges.

Connolly et al. (2018) describe notable civil engineering features of four cities in Europe that recently received the European Green Capital
Award. All four have set a remarkable standard of environmental, sustainable and smart-city living through a combination of technical innovation and active engagement with citizens.

Finally, Cooke (2018) discusses design and development challenges in the hot Gulf region, ranging from high consumption of environmental resources to poor land-use. The author proposes a paradigm shift to ensure urban landscape schemes include connectivity, stewardship, water resources management and people-centric design.

The papers represent diverse perspectives on how civil engineers can tackle the challenges facing future cities, thereby reinventing our profession while addressing the UN sustainable development goals (UN, 2015) in the infrastructure sector. We hope you find them enjoyable and informative, and that they inspire you to share your own experiences through this and other ICE Proceedings journals.

\section{References}

Clancy L, Palmer S and Blake J (2018) Developing and procuring London's highway infrastructure to enable an electric future. Proceedings of the Institution of Civil Engineers - Civil Engineering 171(6): 45-50, https://doi. org/10.1680/jcien.18.00013

Connolly L, Campion L and Rudden P (2018) European cities continue to grow greener. Proceedings of the Institution of Civil Engineers - Civil Engineering 171(6): 51-56, https://doi.org/10.1680/jcien.18.00011.

Cooke R (2018) Urban and landscape design in the Arabian Gulf region: a new paradigm for sustainability. Proceedings of the Institution of Civil Engineers Civil Engineering 171(6): 57-64, https://doi.org/10.1680/jcien.18.00016.

Dolman N and Ogunyoye F (2018) How water challenges can shape tomorrow's cities. Proceedings of the Institution of Civil Engineers - Civil Engineering 171(6): 22-30, https://doi.org/10.1680/jcien.17.00052.

Hoornweg D, Hosseini M and Kennedy C (2018) Sustainability cost curves for urban infrastructure planning. Proceedings of the Institution of Civil Engineers - Civil Engineering 171(6): 11-21, https://doi.org/10.1680/jcien.18.00005.

ICE (Institution of Civil Engineers) (2018) What is Civil Engineering? ICE, London, UK. See https://www.ice.org.uk/what-is-civil-engineering (accessed 17/08/2018)

Jackson G (2018) Delivering urban energy and transport links using offshore structures. Proceedings of the Institution of Civil Engineers - Civil Engineering 171(6): 39-44, https://doi.org/10.1680/jcien.18.00008.

Rogers CDF (2018) Engineering future liveable, resilient, sustainable cities using foresight. Proceedings of the Institution of Civil Engineers - Civil Engineering 171(6): 3-9, https://doi.org/10.1680/jcien.17.00031.

UN (United Nations) (2014) World's Population Increasingly Urban With More Than Half Living in Urban Areas. UN, New York, NY, USA. See http:// www. un org/en/development/desa/news/population/world-urbanizationprospects-2014.html (accessed 17/08/2018)

UN (2015) Sustainable Development Goals. UN, New York, NY, USA See https://www.un.org/sustainabledevelopment/sustainable-developmentgoals/ (accessed 17/08/2018).

von der Tann L, Metje N, Admiraal H and Collins B (2018) The hidden role of the subsurface for cities. Proceedings of the Institution of Civil Engineers Civil Engineering 171(6): 31-37, https://doi.org/10.1680/jcien.17.00028.

World Bank (2009) World Development Report 2009: Reshaping Economic Geography. World Bank, Washington, DC, USA 